\title{
Manipulating the fatty acid composition of muscle and adipose tissue in beef cattle
}

\author{
Nigel D. Scollan ${ }^{1}$, Nag-Jin Choi ${ }^{1}$, Esra Kurt ${ }^{2}$, Alan V. Fisher ${ }^{2}$, Mike Enser $^{2}$ and Jeff D. Wood ${ }^{2}$ \\ ${ }^{1}$ Institute of Grassland and Environmental Research, Plas Gogerddan, Aberystwyth SY23 3EB, UK \\ ${ }^{2}$ Division of Food Animal Science, University of Bristol, Langford, Bristol BS40 5DU, UK
}

(Received 3 December 1999 - Revised 7 June 2000 - Accepted 22 August 2000)

\begin{abstract}
Enhancing the $n-3$ polyunsaturated fatty acid (PUFA) content of beef is important in view of the generally saturated nature of fatty acids in ruminant meats and the negative effect this can have on human health. This study examined the effects of different sources of dietary $n-3$ PUFA on the performance of steers and the fatty acid composition of $m$. longissimus thoracis muscle and associated subcutaneous adipose tissue. Animals were fed ad libitum on grass silage plus one of four concentrates (60:40 forage:concentrate on a DM basis) containing differing sources of lipid: Megalac (16:0), lightly bruised whole linseed (18:3n-3), fish oil (20:5n-3 and 22:6n-3) and a mixture of linseed and fish oil (1:1, on an oil basis). Diets were formulated so that total dietary oil intake was $6 \%$, approximately half of which was from the experimental test oil. Linseed feeding not only increased the levels of $18: 3 n-3$ in muscle phospholipid from 9.5 to $19 \mathrm{mg} /$ $100 \mathrm{~g}$ muscle but also enhanced the synthesis of $20: 5 n-3$, the level of which increased from 10 to $15 \mathrm{mg} / 100 \mathrm{~g}$ muscle. Linseed also increased the proportion of 18:3n-3 in muscle neutral lipid and in adipose tissue lipids by a factor of 1.64 and 1.75 respectively. Fish oil feeding doubled the proportion of 20:5n-3 and 22:6n-3 in muscle phospholipids. The proportion of 18:1 trans in muscle neutral lipid was higher on the $n-3$ PUFA diets than the control diet, 0.04 and 0.02 respectively. Despite the implied modification to rumen metabolism, lipid source did not affect feed intake, growth rate, cold carcass weight or carcass fatness, but carcass conformation score was higher on fish oil treatments $(P<0.05)$. However, total muscle fatty acid content was not different between treatments and ranged from $3 \cdot 5-4.3 \%$ of tissue weight. The increase in $n-3$ PUFA in the meat produced by feeding linseed or fish oil lowered the $n-6: n-3$ ratio but had little effect on the P:S ratio.
\end{abstract}

Beef: Fatty acids: Health

High levels of fat consumption and particularly of saturated fatty acids are considered to predispose man to several of the so-called 'Diseases of Western Civilisation', notably coronary heart disease (Department of Health, 1994). Current recommendations are that the contributions of fat and saturated fatty acids to dietary energy intake should be reduced to below $0 \cdot 35$ and $0 \cdot 10$ of total intake, respectively, the ratio of the unsaturated to saturated fatty acids should be around 0.45 and intakes of $n-3$ polyunsaturated fatty acids (PUFA) should be increased relative to $n-6$ PUFA (Department of Health, 1994). The precursor for the $n-3$ series is $\alpha$-linolenic (18:3n-3), man having the capacity to synthesis the $\mathrm{C}_{20}$ PUFA, eicosapentaenoic acid (20:5n-3) and, to a lesser extent, docosahexaenoic acid (22:6n-3), from 18:3n-3. The Department of Health (1994) recommends an increase in the consumption of these $n-3$ fatty acids to overcome the imbalance in the ratio of $n-6: n-3$ PUFA in the current diets $(10: 1)$ compared to primitive man $(1: 1$, Eaton et al. 1996), which results from the consumption of plant oils rich in linoleic acid $(18: 2 n-6)$. Meat, fish, fish oils and eggs are the only significant sources of these $n-3 \mathrm{C}_{20}$ PUFA for man. Although meat has lower concentrations of these fatty acids compared to oily fish, it is a very significant source for many people, since fish consumption is low. Hence, enhancing the levels of these fatty acids in meat would help to combat the negative image of beef attributed to its highly saturated nature.

The low PUFA concentrations and the high concentrations of saturated fatty acids in ruminant tissues result from the biohydrogenation of dietary PUFA in the rumen

\footnotetext{
Abbreviation: PUFA, polyunsaturated fatty acid.

* Corresponding author: Dr N. D. Scollan, fax + 44 (0) 1970 828357, email nigel.scollan@BBSRC.ac.uk
} 
(Harfoot \& Hazlewood, 1988). Efforts to increase the PUFA content of ruminant tissues have used different procedures to attempt to bypass ruminal biohydrogenation. These have involved the feeding of chemically or physically modified oils or oil seeds mainly supplying 18:2n-6 (Scott \& Ashes, 1993). The potential to enrich ruminant tissues with $\mathrm{C}_{20} n-3$ PUFA was highlighted when it was demonstrated that ruminal microorganisms in vitro did not hydrogenate 20:5n-3 and 22:6n-3 to any significant extent (Ashes et al. 1992). It may also be feasible to enhance these fatty acids by encouraging de novo synthesis from $18: 3 n-3$ in the tissues, by incorporating linseed, which is high in $18: 3 n-3$, into the diet. The objective of this experiment was to investigate the impact of feeding different sources of long chain PUFA on animal performance and on the intramuscular fatty acid composition of beef. A summary of this study was presented previously (Scollan et al. 1997).

\section{Materials and methods}

\section{Experimental design and treatments}

Thirty-two Charolais steers with an initial live weight of $436 \mathrm{~kg}$ (SE 3.36) were randomly allocated to one of four treatments, resulting in eight animals per treatment. The formulation and chemical composition of the four experimental concentrates is given is Table 1. The concentrates, which were based on barley and sugarbeet pulp, contained differing sources of lipid: Diet 1, Megalac (experimental control, high in the saturated palmitic acid, 16:0, from palm oil); Diet 2, whole linseed (high in $\alpha$-linolenic acid, 18:3n-3); Diet 3, fish oil (high in eicosapentaenoic acid, 20:5n-3 and docosahexaenoic acid, 22:6n-3); and Diet 4, linseed plus fish oil in equal amounts on an oil basis. Diets were formulated so that total dietary oil intake was $6 \%$ of which approximately $3 \%$ was from the experimental test oil. Vitamin E content of the concentrates was $345 \mathrm{IU} / \mathrm{kg}$.

\section{Procedures and measurements}

Animals were housed in a well-ventilated barn and those within a treatment group were penned together and bedded on wood shavings. Animals were individually fed via Calan Broadbent gates and had free access to fresh water. At the beginning of the experiment, during a $14 \mathrm{~d}$ covariate period, all animals were fed on grass silage ad libitum and rolled barley was allocated individually to provide 0.3 of DM intake. The animals were then introduced to their allocated dietary treatment over a $7 \mathrm{~d}$ period. Feed levels were adjusted to grass silage ad libitum and concentrate at 60:40, forage: concentrate on a DM basis. During the $14 \mathrm{~d}$ covariate period feed intake was recorded and live weight measurements were made on five occasions. During the main experimental period, feed intake was recorded and weekly live weights were recorded. All weighings were conducted at the same time of day $(13: 30 \mathrm{~h})$ to reduce variations due to diurnal patterns of feed intake.

Grass silage was fed at $14: 00 \mathrm{~h}$ daily, and the concentrates in two equal portions at 09:00 $\mathrm{h}$ and 16:30 h. The grass silage and concentrates were sampled three times per week for DM analysis in a forced-air oven at $105^{\circ} \mathrm{C}$. Silage was offered at $110 \%$ of the previous consumption. Concentrates feed levels were adjusted weekly, based on the previous week's silage consumption. Samples of silage and concentrate were accumulated over 4-week periods and chemical composition assessed as described by Dewhurst et al. (1999). Feed refusals were measured three times per week.

Table 1. Formulation and chemical composition of the components of the experimental diets (Values are $\mathrm{g} / \mathrm{kg}$ fresh weight for ingredients and $\mathrm{g} / \mathrm{kg}$ DM for chemical composition)

\begin{tabular}{|c|c|c|c|c|c|}
\hline & \multirow[b]{2}{*}{ Silage } & \multirow[b]{2}{*}{ Control } & \multicolumn{3}{|c|}{ Concentrates } \\
\hline & & & Linseed & Fish oil & Linseed-fish oil \\
\hline \multicolumn{6}{|l|}{ Ingredient } \\
\hline Barley & & 638 & 489 & 648 & 569 \\
\hline Sugarbeet pulp & & 213 & 213 & 213 & 213 \\
\hline Molasses & & 64 & 64 & 64 & 64 \\
\hline Megalac & & 64 & - & - & - \\
\hline Fish oil & & - & - & 54 & 27 \\
\hline Linseed & & - & 213 & - & 106 \\
\hline Mineral and vitamin premix & & 21 & 21 & 21 & 21 \\
\hline \multicolumn{6}{|l|}{ Chemical composition } \\
\hline & 258 & 904 & 902 & 906 & 901 \\
\hline $\mathrm{pH}$ & 3.7 & NA & NA & NA & NA \\
\hline Total nitrogen & $22 \cdot 6$ & $19 \cdot 4$ & $25 \cdot 0$ & $18 \cdot 6$ & $22 \cdot 1$ \\
\hline Ammonia-nitrogen & 1.44 & NA & NA & NA & NA \\
\hline Acid detergent insoluble nitrogen & 0.74 & 0.81 & 0.79 & 0.58 & 0.69 \\
\hline Organic matter & 921.0 & $927 \cdot 8$ & 933.9 & $941 \cdot 3$ & 933.5 \\
\hline Neutral detergent fibre & 475 & 225 & 218 & 211 & 206 \\
\hline Acid detergent fibre & 283 & 86 & 108 & 92 & 100 \\
\hline Water-soluble carbohydrates & 14.5 & ND & ND & ND & ND \\
\hline Acid hydrolysis ether extract & $42 \cdot 7^{*}$ & $77 \cdot 3$ & $106 \cdot 5$ & 82.4 & $96 \cdot 9$ \\
\hline Acetic acid & $29 \cdot 6$ & NA & NA & NA & NA \\
\hline
\end{tabular}

NA, not applicable; ND, not determined.

* Silage value is based on ether extract only and not acid hydrolysis ether extract. 
Animals remained on treatment on average $120 \mathrm{~d}$. Eight animals were slaughtered each week over a 4-week period. Animals were selected for slaughter on a live weight basis; the two heaviest animals in each group were selected for slaughter each week. Animals were transported to Bristol on the day before slaughter. Cold carcass weights (excluding kidney knob and channel fat), external fatness and conformation scores were assessed as described by Kempster et al. (1986), by the same individual.

Complete cross-sections of the $m$. longissimus thoracis 10-12 rib level, $15 \mathrm{~mm}$ thick were freed of epimysium and adhering adipose tissue. The muscle was blended in a food processor and the lipids extracted from duplicate $10 \mathrm{~g}$ samples using chloroform:methanol (2:1, v/v; Folch et al. 1957). Neutral lipid and phospholipids were isolated from the lipid extract using silicic acid chromatography. Extracted lipid, 20-30 mg in approximately $1.0 \mathrm{ml}$ chloroform was applied to a $500 \mathrm{mg}$ silicic acid column (Isolute $\mathrm{Si}$, Jones Chromatography, Hengoed, Glamorgan, UK) previously washed extensively with chloroform. The neutral lipid fraction was eluted with $10 \mathrm{ml}$ chloroform and the phospholipid fraction (polar lipids) with $20 \mathrm{ml}$ methanol. After the addition of the fatty acid standard, heneicosanoic acid methyl ester (Sigma, Gillingham, UK), the solvents were removed under nitrogen and the lipids hydrolysed with $2 \mathrm{M}$ potassium hydroxide in methanol:water $(1: 1, \mathrm{v} / \mathrm{v})$, containing $1 \mathrm{~g} / \mathrm{l}$ hydroquinone as antioxidant, at $60^{\circ} \mathrm{C}$ for $1 \mathrm{~h}$. After dilution with water and removal of nonsaponifiables by three extractions with petroleum spirit (BP $40-60^{\circ} \mathrm{C}$ ), the hydrolysate was acidified and the fatty acids extracted into petroleum spirit. After neutralisation and drying, with solid sodium hydrogencarbonate and anhydrous sodium sulphate, the fatty acids were methylated with a solution of diazomethane in diethyl ether and their composition determined by gas-liquid chromatography. Samples were injected in the split mode, 70:1, onto a CP Sil $88,50 \mathrm{~m} \times 0.25 \mathrm{~mm}$ fatty acid methyl esters (FAME) column (Chrompack UK Ltd, London) with helium as the carrier gas. The output from the flame ionization detector was quantified using a computing integrator (Spectra Physics 4270) and linearity of the system was tested using saturated (FAME4) and monounsaturated (FAME5) methyl ester quantitative standards (Thames Restek UK Ltd, Windsor, UK).

Adipose tissue fatty acid composition was determined in the subcutaneous adipose tissue over the $m$. longissimus thoracis at the 10th-12th rib. A sample of the complete thickness of the tissue was blended in a food processor. Lipid was extracted by homogenizing duplicate $1 \mathrm{~g}$ samples in chloroform containing 2,6-di-tert-butyl- $p$-cresol $(100 \mathrm{mg} / \mathrm{l})$ as antioxidant and then adding anhydrous sodium sulphate to remove water. After filtration, samples were taken and hydrolysed and the fatty acids processed and analysed as above.

Lipids were extracted from the silage by the method of Bauchart et al. (1984) and then converted to methyl esters as described for tissue lipids. Concentrate fatty acids were attained by direct hydrolysis in $5 \mathrm{M}$ potassium hydroxide in aqueous methanol $(1: 1, \mathrm{v} / \mathrm{v})$ for $3 \mathrm{~h}$ at $60^{\circ} \mathrm{C}$ after addition of 21:0 methyl ester as an internal standard. After acidification the samples were heated for an additional $1 \mathrm{~h}$ before extraction of the fatty acids.

Fatty acid results are given as proportion times 100 , or as $\mathrm{mg}$ of fatty acid per $100 \mathrm{~g}$ wet tissue quantified by reference to the internal standard. Only the major fatty acids and minor components readily identified and relevant to the study are reported, representing over $90 \%$ of the total fatty acids present. The fatty acid reported as $16: 1 \mathrm{cis}$ consists of both the $n-9$ and $n-7$ isomers and contaminating branched seventeen-carbon fatty acids. The trans 18:1 isomers are incompletely resolved by this column and are reported as one value. In view of the complexity of the chromatogram in this area as a result of the wide range of 18:1 isomers in ruminant tissues (Hay \& Morrison, 1972), some minor cross-contamination of the listed 18:1 isomers may be present.

\section{Statistical analysis}

Live weight growth rates $(\mathrm{g} / \mathrm{d})$ for each animal were estimated from regression of live weight on time. Average daily feed intakes of silage and concentrate were calculated for the experimental period. The visual scores for carcass fatness and conformation of the EU Carcass Classification Scheme were converted to numerical values by multiplying the values for estimated fat and conformation by 10 (Kempster et al. 1986). All the data were subjected to analysis of variance (Genstat 5; Lawes Agricultural Trust, 1994).

\section{Results}

\section{Animal performance and carcass classification}

The animal performance and carcass classification data are presented in Table 2. Lipid source did not influence feed intake or growth rate. Cold carcass weights were similar across treatments, average $333.7 \mathrm{~kg}$. Carcass conformation was highest on the fish oil treatments in comparison to either the control or linseed $(P<0 \cdot 05)$, but no significant differences were noted for carcass fatness.

\section{Fatty acid composition}

The fatty acid composition of neutral lipid and phospholipid fatty acids expressed as proportion times 100 are shown in Tables 3 and 5 and the tissue content of the two lipid fractions expressed as $\mathrm{mg}$ per $100 \mathrm{~g}$ of muscle in Tables 4 and 6 , respectively. Intramuscular fatty acid content was not significantly different between treatments with neutral lipid fatty acids varying from 2.9 to 3.9 g per $100 \mathrm{~g}$ tissue and phospholipid fatty acids from 0.45 to $0.50 \mathrm{~g}$ per $100 \mathrm{~g}$ tissue.

\section{Neutral lipids}

The three major fatty acids in the neutral lipids were $18: 1 n$ 9, 16:0 and 18:0 whose combined proportions were approximately $0 \cdot 75$. There were marked treatment effects on the proportions of these fatty acids although these were not apparent when the results were expressed as mg fatty 
Table 2. Animal performance and carcass classification in Charolais steers fed on diets containing different sources of lipid (Values are means and standard error for eight animals per diet; residual degrees of freedom 31)

\begin{tabular}{|c|c|c|c|c|c|c|}
\hline & Control & Linseed & Fish oil & Linseed-fish oil & SEM & $P$ value \\
\hline Silage DM intake (kg/d) & 5.43 & 5.43 & $5 \cdot 12$ & $5 \cdot 37$ & 0.124 & NS \\
\hline Concentrate DM intake $(\mathrm{kg} / \mathrm{d})$ & 3.61 & 3.62 & 3.46 & 3.60 & 0.082 & NS \\
\hline Live weight gain $(\mathrm{kg} / \mathrm{d})$ & $1 \cdot 29$ & $1 \cdot 25$ & $1 \cdot 38$ & $1 \cdot 36$ & 0.056 & NS \\
\hline \multicolumn{7}{|l|}{ Carcass weight and classification } \\
\hline Cold carcass weight (kg) & $333 \cdot 1$ & $330 \cdot 1$ & 334.4 & $337 \cdot 3$ & 4.56 & NS \\
\hline Conformation† & $91 \cdot 3$ & 83.8 & $105 \cdot 6$ & $105 \cdot 6$ & $5 \cdot 60$ & * \\
\hline External fatness† & 84.4 & $79 \cdot 7$ & $85 \cdot 3$ & $81 \cdot 6$ & $4 \cdot 32$ & NS \\
\hline
\end{tabular}

NS, not significant $P>0.05$.

${ }^{*}$, ${ }^{* *}$ and ${ }^{* * *}$ refer to significance levels $P<0.05, P<0.01$ and $P<0.001$ respectively.

† Fatness and conformation scores were converted to numerical values using the procedure of Kempster et al. (1986).

acid per $100 \mathrm{~g}$ muscle because of the large variability in the quantity of marbling fat between animals. Compared with fat from animals fed the control diet, the fat from animals fed the linseed diet had lower proportions of 16:0 and 18:0 and the fat from animals on the fish oil diet had a higher proportion of $16: 0$ and lower proportions of 18:0 and $18: 1 n-9$. The concentration and proportion of 18:1 trans was much higher in the steers given the unsaturated lipid supplements $(P<0.001)$ with an average proportion of $0 \cdot 044$ compared with $0 \cdot 019$. The proportion of $18: 2 n-6$ was decreased by feeding the $n-3$ PUFA in linseed and fish oils $(P<0.001)$ whereas the concentration and proportion of 18:3n-3 was almost doubled by feeding linseed.

\section{Phospholipids}

The concentration of phospholipid fatty acids was not affected significantly by diet; the mean value across treatments being $462 \mathrm{mg}$ per $100 \mathrm{~g}$ muscle. As with the neutral lipids, the major fatty acids were 18:1n-9 followed by $16: 0$ and then 18:0 but their proportions were one-third or more less than in the neutral lipid fraction. The effect of diet on these three fatty acids in the phospholipids was also similar to that in the neutral lipid. There was a lower proportion of 16:0 acid as a result of feeding the linseed diet compared with the control diet but the proportion of 18:0 was not different. However, compared to the control diet, fish oil did not alter the proportion of 16:0 but produced lower proportions of $18: 0$ and 18:1n-9. The quantity of 18:1 trans contributed to muscle lipids by the phospholipid fraction was on average $6.6 \mathrm{mg}$ compared with $123 \mathrm{mg}$ in the neutral lipids. The concentration and proportion of 18:1 trans was higher in the phospholipids of animals fed the unsaturated fatty acids compared with the control animals fed megalac, with the fish oil diet producing the highest concentration, threefold higher than in the controls. The concentrations of $18: 2 n-6$ were not significantly different between treatments but the proportions were significantly lower $(P<0.05)$ on the diets containing fish oil. Feeding linseed doubled the amount and proportion of 18:3n-3 with the mixed linseed-fish oil diet producing intermediate levels. The major long-chain PUFA with twenty or more carbon atoms were 20:4n-6 followed by $22: 5 n-3$ and $20: 5 n-3$ in muscles from megalac-fed steers. The diets containing the $n-3$ PUFA resulted in higher proportions of the long-chain $n$-3 PUFA and lower proportions of long-chain n-6 PUFA except for 22:5n-3, the proportions of which were very slightly affected by the fish oil diet only. The linseed diet resulted in significant increases in the proportion of 20:4n-3 (twofold) and 20:5n3 (1.5-fold) but not $22: 6 n-3$ or $22: 4 n-3$ whereas the fish oil diet also increase 22:6n-3 (twofold) and 22:4 n-3 (fourfold). Interestingly, the proportions of 22:6n-3 were similar with the fish oil and linseed-fish oil mixed diet.

Table 3. Fatty acid composition (proportion $\times 100$ ) of the neutral lipids of $m$. longissimus thoracis from Charolais steers fed on diets containing different sources of lipid

(Values are means and standard errors for eight animals per diet; residual degrees of freedom 31)

\begin{tabular}{|c|c|c|c|c|c|c|}
\hline & Control & Linseed & Fish oil & Linseed-fish oil & SEM & $P$ value \\
\hline 12:0 lauric & 0.12 & 0.12 & 0.12 & 0.12 & 0.017 & NS \\
\hline 14:0 myristic & $3 \cdot 72$ & $4 \cdot 10$ & 4.57 & $4 \cdot 36$ & 0.421 & NS \\
\hline 16:0 palmitic & $30 \cdot 0$ & $27 \cdot 1$ & $32 \cdot 0$ & $29 \cdot 0$ & 0.931 & 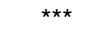 \\
\hline $16: 1$ cis & 3.73 & 4.02 & $4 \cdot 18$ & $4 \cdot 21$ & 0.235 & NS \\
\hline 18:0 stearic & $15 \cdot 8$ & $14 \cdot 2$ & $13 \cdot 2$ & 12.9 & 0.684 & $* * *$ \\
\hline 18:1 trans & 1.93 & 3.76 & 4.43 & 4.95 & 0.459 & $* * *$ \\
\hline $18: 1 n-9$ oleic & $36 \cdot 0$ & $35 \cdot 7$ & $30 \cdot 1$ & $33 \cdot 2$ & 1.57 & $* *$ \\
\hline $18: 1$ cis vaccenic & 0.92 & 1.04 & 0.97 & 0.91 & 0.103 & NS \\
\hline $18: 2 n-6$ linoleic & 0.93 & 0.79 & 0.57 & 0.72 & 0.075 & $\star \star \star$ \\
\hline $18: 3 n-3 \alpha$-linolenic & 0.36 & 0.59 & 0.38 & 0.41 & 0.043 & $* * *$ \\
\hline
\end{tabular}

NS, not significant $P>0.05$

${ }^{\star \star} P<0.01 ;{ }^{\star \star \star} P<0.001$. 
Table 4. Fatty acid content, (mg per $100 \mathrm{~g}$ muscle) of the neutral lipids of $\mathrm{m}$. Iongissimus thoracic from Charolais steers fed on diets containing different sources of lipid

(Values are means and standard errors for eight animals per diet; residual degrees of freedom 31)

\begin{tabular}{|c|c|c|c|c|c|c|}
\hline & Control & Linseed & Fish oil & Linseed-fish oil & SEM & $P$ value \\
\hline 12:0 lauric & 3.5 & 3.8 & 4.4 & $3 \cdot 7$ & 0.92 & NS \\
\hline 14:0 myristic & 112 & 130 & 178 & 131 & 30.4 & NS \\
\hline 16:0 palmitic & 872 & 851 & 1247 & 853 & 167 & NS \\
\hline $16: 1 \mathrm{cis}$ & 110 & 126 & 162 & 125 & $23 \cdot 7$ & NS \\
\hline 18:0 stearic & 449 & 451 & 521 & 374 & 82.4 & NS \\
\hline $18: 1$ trans & 57 & 120 & 175 & 139 & $26 \cdot 4$ & *** \\
\hline $18: 1 n-9$ oleic & 1039 & 1150 & 1171 & 975 & 206 & NS \\
\hline $18: 1$ cis vaccenic & 27 & 32 & 38 & 27 & $6 \cdot 2$ & NS \\
\hline $18: 2 n-6$ linoleic & 27 & 25 & 23 & 20 & 4.9 & NS \\
\hline $18: 3 n-3 \alpha$-linolenic & 10 & 19 & 15 & 12 & 2.9 & * \\
\hline Total fatty acids & 2903 & 3180 & 3900 & 2922 & 567 & NS \\
\hline
\end{tabular}

NS, not significant, $P>0.05$

${ }^{\star} P<0.05 ;{ }^{\star \star \star} P<0.001$

\section{Subcutaneous adipose tissue}

The effect of dietary lipid on the fatty acid composition of the subcutaneous adipose tissue (proportion times 100) and on the total fatty acid content of adipose tissue (mg per $100 \mathrm{~g}$ tissue) are shown in Table 7. Adipose tissue from the steers given the feeds containing fish oil had a slightly lower $(P<0.05)$ content of lipid than the animals on the control feed. As in muscle the major fatty acids were 18:1n9, 16:0 and 18:0, which together contributed 0.78 of the total fatty acids in animals on the control diet. Compared with the latter, linseed feeding gave lower 16:0 but did not affect $18: 1 n-9$ or 18:0 but doubled the proportion of $18: 1$ trans and increased the proportion (times 100) of 18:3n-3 from 0.37 to $0 \cdot 65$. The adipose tissue from animals fed the fish oil diet differed most from the control with significantly high proportions of 12:0, 14:0, 16:0 and 18:1 trans. However, the proportion of $18: 1 n-9$ and $18: 2 n-6$ were less. The diet containing a mixture of linseed and fish oil gave a fatty acid composition between that of the two dietary lipids fed separately. No $\mathrm{C}_{20}$ or $\mathrm{C}_{22}$ PUFA were detected in the adipose tissue lipid.

\section{Nutritional indices}

Fatty acid ratios related to healthy human nutrition are shown in Table 8. The results for the muscle were calculated from the combined neutral lipid and phospholipid fractions. In muscle P:S ratios tended to be higher in the control and linseed treatments than in fish or mixture treatments. However, in adipose tissue the P:S ratios of the linseed treatments were significantly higher than those of the control, with the lowest values for the fish oil diet. The $18: 2 n-6$ to $18: 3 n-3$ ratio was lower in all three unsaturated treatments compared to the control $(P<0.001)$ in both muscle and adipose tissue. When the ratio was calculated as total $n$-6:total $n$-3 for muscle the ratios were further improved falling to half the control value for the fish oil diet.

Table 5. Fatty acid composition (proportion $\times 100$ ) of the phospholipids of $\mathrm{m}$. longissimus thoracis from Charolais steers fed on diets containing different sources of lipid

(Values are means and standard errors for eight animals per diet; residual degrees of freedom 31)

\begin{tabular}{|c|c|c|c|c|c|c|}
\hline & Control & Linseed & Fish oil & Linseed-fish oil & SEM & $P$ value \\
\hline 12:0 lauric & 0.05 & 0.04 & 0.05 & 0.04 & 0.012 & NS \\
\hline $14: 0$ myristic & 0.74 & 0.58 & 0.94 & 0.71 & 0.205 & NS \\
\hline 16:0 palmitic & $17 \cdot 2$ & $14 \cdot 7$ & $17 \cdot 5$ & $15 \cdot 5$ & 0.894 & * \\
\hline $16: 1$ cis & $2 \cdot 20$ & $2 \cdot 01$ & $2 \cdot 28$ & $2 \cdot 30$ & 0.190 & NS \\
\hline $18: 0$ stearic & 10.5 & $10 \cdot 4$ & 9.7 & 9.6 & 0.335 & * \\
\hline $18: 1$ trans & 0.59 & 1.31 & 1.85 & 1.78 & 0.227 & *** \\
\hline $18: 1 n-9$ oleic & 23.4 & 21.6 & $17 \cdot 4$ & $20 \cdot 7$ & 1.63 & $\star \star$ \\
\hline $18: 1$ cis vaccenic & 1.67 & 1.75 & 2.28 & 1.94 & 0.182 & * \\
\hline $18: 2 n-6$ linoleic & 11.4 & $10 \cdot 1$ & 8.4 & 9.2 & 1.03 & * \\
\hline $18: 3 n-3 \alpha$-linolenic & $2 \cdot 13$ & $4 \cdot 34$ & 2.37 & 3.49 & 0.33 & *** \\
\hline $20: 3 n-6$ & 1.50 & $1 \cdot 23$ & $1 \cdot 10$ & 0.98 & 0.131 & ** \\
\hline $20: 4 n-6$ arachidonic & 5.09 & 4.47 & 2.96 & 3.87 & 0.377 & *** \\
\hline $20: 4 n-3$ & 0.48 & 0.97 & 3.46 & 1.42 & 0.341 & $\star * *$ \\
\hline 20:5n-3 eicosapentaenoic & $2 \cdot 31$ & 3.55 & 4.87 & 3.60 & 0.440 & $\star \star \star *$ \\
\hline $22: 4 n-6$ & 0.46 & 0.30 & 0.21 & 0.26 & 0.051 & 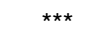 \\
\hline $22: 4 n-3$ & 0.10 & 0.13 & 0.41 & 1.02 & 0.106 & *** \\
\hline $22: 5 n-3$ docosapentaenoic & 4.26 & 4.64 & 4.81 & 4.51 & 0.286 & NS \\
\hline $22: 6 n-3$ docosahexaenoic & 0.55 & 0.63 & 1.08 & 1.22 & 0.117 & $\star * * *$ \\
\hline
\end{tabular}

NS, not significant, $P>0.05$

${ }^{\star} P<0.05 ;{ }^{\star \star} P<0.01 ;{ }^{\star \star *} P<0.001$ 
Table 6. Fatty acid content (mg per $100 \mathrm{~g}$ muscle) of the phospholipids of $\mathrm{m}$. longissimus thoracis from Charolais steers fed on diets containing different sources of lipids

(Values are means and standard errors for eight animals per diet; residual degrees of freedom 31)

\begin{tabular}{|c|c|c|c|c|c|c|}
\hline & Control & Linseed & Fish oil & Linseed-fish oil & SEM & $P$ value \\
\hline 12:0 lauric & 0.24 & 0.15 & 0.26 & 0.17 & 0.070 & NS \\
\hline 14:0 myristic & 4.0 & $2 \cdot 7$ & $5 \cdot 0$ & $3 \cdot 3$ & 1.490 & NS \\
\hline 16:0 palmitic & 81 & 65 & 89 & 70 & 11.94 & NS \\
\hline $16: 1$ cis & 10 & $8 \cdot 8$ & 12 & 10 & 1.564 & NS \\
\hline 18:0 stearic & 44 & 46 & 49 & 44 & $5 \cdot 81$ & NS \\
\hline $18: 1$ trans & 3.0 & 5.9 & 9.7 & $7 \cdot 9$ & 1.484 & $\star \star \star \star ~$ \\
\hline $18: 1 n-9$ oleic & 107 & 96 & 87 & 94 & 13.68 & NS \\
\hline $18: 1$ cis vaccenic & 7.5 & $7 \cdot 7$ & 11.4 & 8.6 & $1 \cdot 104$ & ** \\
\hline 18:2n-6 linoleic & 51 & 44 & 40 & 41 & $4 \cdot 12$ & NS \\
\hline $18: 3 n-3 \alpha$-linolenic & 9.5 & 19 & 12 & 16 & 1.568 & $\star \star \star *$ \\
\hline $20: 3 n-6$ & 6.5 & $5 \cdot 3$ & 5.4 & 4.4 & 0.514 & ** \\
\hline $20: 4 n-6$ arachidonic & 22 & 19 & 14 & 17 & 1.518 & 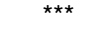 \\
\hline $20: 4 n-3$ & $2 \cdot 1$ & 4.3 & $17 \cdot 9$ & 6.4 & 2.049 & $\star \star \star \star ~$ \\
\hline 20:5n-3 eicosapentaenoic & 10 & 15 & 24 & 16 & $2 \cdot 257$ & $* \star *$ \\
\hline $22: 4 n-6$ & $2 \cdot 0$ & 1.3 & 1.0 & 1.2 & 0.199 & $\star \star \star *$ \\
\hline $22: 4 n-3$ & 0.46 & 0.59 & $5 \cdot 3$ & $1 \cdot 8$ & 0.664 & $\star \star \star \star ~$ \\
\hline $22: 5 n-3$ docosapentaenoic & 19 & 20 & 24 & 20 & $1 \cdot 382$ & ** \\
\hline 22:6n-3 docosahexaenoic & 2.5 & $2 \cdot 7$ & $5 \cdot 3$ & 5.5 & 0.490 & 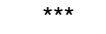 \\
\hline Total fatty acids & 456 & 438 & 500 & 451 & $44 \cdot 2$ & NS \\
\hline
\end{tabular}

NS, not significant $P>0.05$

${ }^{* *} P<0.01 ;{ }^{* \star *} P<0.001$

Table 7. Fatty acid composition (proportion $\times 100$ ) and content of the subcutaneous adipose tissue of Charolais steers fed on diets containing different sources of lipids

(Values are means and standard errors for eight animals per diet; residual degrees of freedom 31)

\begin{tabular}{|c|c|c|c|c|c|c|}
\hline & Control & Linseed & Fish oil & Linseed-fish oil & SEM & $P$ value \\
\hline 12:0 lauric & 0.07 & 0.08 & 0.10 & 0.09 & 0.012 & * \\
\hline 14:0 myristic & 4.0 & 3.9 & 5.4 & 4.5 & 0.400 & ** \\
\hline 16:0 palmitic & $28 \cdot 5$ & 24.4 & $30 \cdot 7$ & $27 \cdot 2$ & 0.663 & 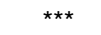 \\
\hline $16: 1 \mathrm{cis}$ & 5.3 & 5.4 & 4.9 & $5 \cdot 1$ & 0.388 & NS \\
\hline 18:0 stearic & $12 \cdot 4$ & $10 \cdot 5$ & $12 \cdot 4$ & $11 \cdot 3$ & 0.847 & NS \\
\hline $18: 1$ trans & $2 \cdot 3$ & 4.7 & $5 \cdot 8$ & 5.9 & 0.464 & $\star \star \star *$ \\
\hline $18: 1 n-9$ oleic & $36 \cdot 7$ & $35 \cdot 4$ & $26 \cdot 1$ & $30 \cdot 7$ & 1.520 & $\star \star \star *$ \\
\hline $18: 1$ cis vaccenic & 1.3 & $1 \cdot 3$ & $1 \cdot 1$ & $1 \cdot 2$ & 0.094 & NS \\
\hline $18: 2 n-6$ linoleic & 0.94 & 0.86 & 0.67 & 0.73 & 0.046 & 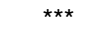 \\
\hline $18: 3 n-3 \alpha$-linolenic & 0.37 & 0.65 & 0.44 & 0.45 & 0.036 & *** \\
\hline Total fatty acids ( $\mathrm{g} / 100 \mathrm{~g}$ adipose tissue) & $90 \cdot 4$ & 88.4 & $85 \cdot 9$ & 87.4 & 1.44 & * \\
\hline
\end{tabular}

NS, not significant, $P>0.05$.

${ }^{\star} P<0.05 ;{ }^{\star \star} P<0.01 ;{ }^{* \star *} P<0.001$.

Table 8. Fatty acid ratios related to healthy nutrition in Charolais steers fed on diets containing different sources of lipid

(Values are means and standard errors for eight animals per diet; residual degrees of freedom 31)

\begin{tabular}{|c|c|c|c|c|c|c|}
\hline & Control & Linseed & Fish oil & Linseed-fish oil & SEM & $P$ value \\
\hline \multicolumn{7}{|l|}{ Muscle } \\
\hline$P: S^{*}$ & 0.067 & 0.067 & 0.045 & 0.051 & 0.008 & NS \\
\hline$(18: 2 n-6) /(18: 3 n-3) \dagger$ & 3.84 & 1.86 & 2.58 & $2 \cdot 17$ & 0.177 & ** \\
\hline$(n-6) /(n-3) \ddagger$ & $2 \cdot 00$ & $1 \cdot 19$ & 0.91 & $1 \cdot 11$ & 0.106 & $\star \star$ \\
\hline \multicolumn{7}{|l|}{ Adipose tissue } \\
\hline$P: S^{*}$ & 0.028 & 0.035 & 0.021 & 0.024 & 0.002 & $\star \star \star *$ \\
\hline$(18: 2 n-6) /(18: 3 n-3) \dagger$ & 2.54 & 1.34 & 1.52 & 1.65 & 0.120 & 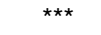 \\
\hline
\end{tabular}

* P:S calculated as $(18: 2 n-6+18: 3 n-3) /(12: 0+14: 0+16: 0+18: 0)$.

$\dagger n-6: n-3$ calculated as $(18: 2 n-6) /(18: 3 n-3)$.

$\ddagger n-6: n-3$ calculated as $(18: 2 n-6+20: 3 n-6+20: 4 n-6) /(18: 3 n-3+20: 4 n-3+20: 5 n-3+22: 5 n-3+22: 6 n-3)$. 


\section{Discussion}

Animal performance and carcass characteristics

Incorporation of lipid into the diet did not influence DM intake, although there was a tendency for intake of the fish oil diet to be lower. Chilliard \& Doreau (1997) reported a reduction of $1.6 \mathrm{~kg}$ DM per d when dairy cows fed on maize and concentrates (at 0.65:0.35 on a DM basis) were supplemented with $300 \mathrm{ml}$ of fish oil (menhaden type) and similar effects have been observed elsewhere (Wonsil et al. 1994; Mandell et al. 1997). It is thought that these effects are mediated by specific fatty acids produced as a result of rumen biohydrogenation rather than a negative effect of the fatty acids of fish oil on rumen function, since the fish oil does not disturb ruminal fibre digestion (Wonsil et al. 1994; Chilliard \& Doreau, 1997). Since intakes were similar across treatments of similar nutrient balance, no differences in live weight gain or carcass fatness were expected (Table 2). Surprisingly, carcass conformation was significantly higher on the fish oil and mix concentrates $(P<0.05)$. This result is difficult to explain although it could indicate a positive effect of fish oil on muscle development.

\section{Tissue fatty acid composition}

Feeding $n$-3 PUFA supplements as bruised linseed or fish oil resulted in significant increases in their deposition in muscle lipids. However, the increases were much less than those obtained when formaldehyde-treated, protein-encapsulated lipids were fed (Cook et al. 1972; Kimoto et al. 1974; McDonald \& Scott, 1977; Ashes et al. 1992). Milk from cows fed formaldehyde-protected linseed oil contained $20 \% 18: 3 n-3$ in the lipid compared with $1 \%$ in milk from cows fed unprotected linseed oil. This illustrates well the extent to which ruminant PUFA are amenable to manipulation if they escape rumen biohydrogenation. Our results suggest that the seed coat of linseed had little effect in protecting 18:3n-3 as confirmed in the associated digestion experiment (Scollan et al. submitted). The increase in adipose tissue 18:3n-3 observed (Table 7) was similar to feeding steam-flaked linseed, which resulted in a doubling of 18:3n-3 in perirenal adipose tissue of bulls (Clinquart et al. 1991). Processing oilseeds (whole, crushing, rolling) is generally far less effective than feeding protected lipid supplements (Kennelly, 1996). The increase in the concentration of 20:5n-3 on the linseed diet (Tables 5 and 6) suggests that increasing the availability of $18: 3 n-3$ has resulted in enhanced synthesis of 20:5n-3 from its precursor 18:3n-3. In light of the increasing pressures to reduce the use of fish products in animal feeds this finding is particularly noteworthy, as an alternative means of enhancing the 20:5n-3 levels in ruminant product.

In ruminants the long-chain $\mathrm{C}_{20}$ and $\mathrm{C}_{22}$ PUFA are found mainly in the tissue phospholipids and not in the triacylglycerol fraction of muscle and adipose tissue (Ashes et al. 1992). The increases in the concentration of 20:5n-3 and 22:6n-3 on feeding either fish meal or fish oil is similar to other studies with poultry, pigs and cattle (Ratnayake et al. 1989; Morgan et al. 1992; Cant et al. 1997; Mandell et al. 1997; Mansbridge \& Blake, 1998).
In this study, the concentration and proportion of 20:5n-3 and 22:6n-3 are similar to that quoted by Marmer et al. (1984) and by Mandell et al. (1997), who also reported that both the amount and duration of fish meal feeding increased intramuscular deposition of these fatty acids. However, the increases in 20:5n-3 and 22:6n-3 were much less than the responses observed when sheep were fed a rumen-protected fish oil supplement (Ashes et al. 1992), suggesting high levels of ruminal biohydrogenation of these fatty acids (Scollan et al. submitted). Surprisingly, $22: 6 n-3$ was incorporated as effectively from the mix treatment (linseed-fish oil) as from the fish oil alone, so that the concentration was similar, on average $4.75 \mathrm{mg} /$ $100 \mathrm{~g}$ muscle.

Since phospholipids constitute a relatively constant component of tissues, increased deposition of $n-3$ PUFA can only occur through displacement of another similar fatty acid usually of the $n-6$ series (Ratnayake et al. 1989). The decreases in the concentration of 20:3n-6 and 20:4n-6 on the unsaturated treatments compared to the control is similar to that noted in other studies using fish meal or fish oil, with both ruminants and non-ruminants (Morgan et al. 1992; Van Elswyck et al. 1992; Mandell et al. 1997). In rats, fish oils were more effective than $\alpha$-linolenic acid in depressing levels of 20:4n-6 (Hwang et al. 1988) similar to the greater reduction in $20: 4 n-6$ by the fish oil treatments compared to the linseed (Tables 4 and 5). The $n$-3 fatty acids also interfere with the synthesis of $20: 4 n-6$ from 18:2n-6 (Ratnayake et al. 1989). However, fish oil supplementation in the work by Ashes et al. (1992) did not affect arachidonic acid, 20:4n-6, in serum or muscle phospholipid, which the authors attributed to adequate $\Delta-6$ desaturase activity ensuring conversion of $18: 2 n-6$ to 20:4n-6.

The proportions of 12:0, 14:0 and 16:1 were not influenced by treatment but the proportion of palmitic acid was decreased by the linseed diet in both neutral lipids and phospholipids of muscle. However, fish oil significantly increased the proportion of 16:0 in the neutral lipids and Mandell et al. (1997) also found that fish meal feeding increased 16:0, contrary to the lack of effect observed by Mills et al. (1992) feeding fish meal and Ashes et al. (1992) who fed ruminally-protected fish oil. Although the concentrations of 18:0 in the muscle were not affected by treatment the proportions in animals fed fish oil or the mixture were lower than in the control animals. In the phospholipids this could result from replacement of 18:0 by 18:1 trans which behaves like a saturated fatty acid in vivo. Lower 18:0 has been reported after fish meal supplementation (Mills et al. 1992; Mandell et al. 1997) but not after feeding fish oil (Ashes et al. 1992) in sheep. In the muscle neutral lipids the proportions of 18:0 (Table 2) were decreased by all the diets with added $n$-3 PUFA but the sum of the 18:0 plus 18:1 trans was similar across all feeds. These compositions are markedly different from the ratios of 18:0 to 18:1 trans in the flow to the duodenum, which were $6 \cdot 6,1 \cdot 8,0 \cdot 8$ and $0 \cdot 8$ respectively for the four feeds (Scollan et al. submitted). This indicates extensive catabolism of 18:1 trans and that fatty acids derived from intestinal absorption may have minimal effects on the composition of depot triacylglycerols, at least in the case of 
saturated and monounsaturated fatty acids. It is noteworthy that the highest amounts of 18:1 trans occurred in steers fed the fish oil containing concentrates despite a lower total PUFA level in the feed compared with the linseed concentrate indicating that long-chain fish oil n-3 PUFA or a degradation product are more inhibitory to the biohydrogenation than $18: 3 n-3$. In the phospholipids the proportion of $18: 1 n-9$ was decreased by the fish-oilcontaining concentrates apparently through substitution by $20: 5 n-3$ and $22: 6 n-3$. Although the duodenal flow of 18:1n-9 was low, 3-4 \% of total fatty acids (Scollan et al. submitted), it was the major fatty acid in both lipid fractions, so that attribution of any effects on tissue levels of differences between the feeds must be tenuous, at least for the neutral lipid fraction.

The proportions of 18:2n-6 in both lipid fractions were significantly lowered by fish oil feeding with a smaller nonsignificant effect of linseed $(P<0.05$; Tables 3 and 5). The similarity between the effects in the neutral and phospholipid fractions suggests that they may result from intestinal availability rather than changes in 20:5n-3 and 22:6n-3 since the latter fatty acids are not present in the neutral lipids. Tissue levels of 18:2n-6 respond very readily to increases in post-rumen availability when protected lipid is fed (Cook et al. 1972) and the tissue levels resulting from the different diets in our study reflect the amounts entering the duodenum in the associated study (Scollan et al. submitted). Much higher deposition of 20:5n-3 and 22:6n-3 than in the present study was needed to displace 18:2n-6 from phospholipids (Dawson et al. 1991; Ashes et al. 1992).

The fatty acid composition of the subcutaneous adipose tissue resembled that of the intramuscular neutral lipids very closely (Tables 4 and 7) but was marginally less saturated with less 16:0 and 18:0. In both cases there was little increase in the proportion of $18: 3 n-3$ present in animals fed the linseed-fish oil mixture compared with those fed fish oil alone, whereas the expected intermediate value occurred in the phospholipids. No obvious explanation is available for this finding. Overall, the fatty acid composition for the adipose tissue lipid is similar to that reported by Marmer et al. (1984) with the values for 18:2n6 and 18:3n-3 in the control group falling between their values for grass and grain finished steers in line with the composition of the basal feed.

\section{Impact on human nutrition}

The COMA report on the nutritional aspects of cardiovascular disease (Department of Health, 1994) recommended the P:S ratio should remain at 0.45 , which is considered appropriate for the human diet as a whole. Hence, the P:S ratios in this study for the total muscle fatty acids (Table 8) were lower than the recommended ratio, and lower than reported for typical retail beef in the UK $(0 \cdot 11$; Enser et al. 1996) and fish-meal-supplemented Charolais steers (0.110.13; Mandell et al. 1997), even when calculated on the same basis. However, imbalances in the P:S can be addressed elsewhere in the diet so of more significance is the $n-6: n-3$ ratio, which was beneficially at or below the recommended value of 2.0 for all treatments. The ratio for the three unsaturated fatty acid treatments was lower than that for the control, on average 1.07 and 2.0 respectively (Table 8) and similar to the diet of primitive man (1.0; Weber et al. 1993). This is in accord with the recommendations of the COMA report (Department of Health, 1994), which advised no change in the intake of $n-6$ PUFA and an increase in the intake of $n$ - 3 PUFA.

The recommended daily consumption of $n-3$ fatty acids is $100-200 \mathrm{mg} / \mathrm{d}$, mainly as $20: 5 n-3$ and 22:6n-3 (Department of Health, 1994). However, in the USA, the consumption of $1 \mathrm{~g} / \mathrm{d}$ of $n-3$ fatty acids is recommended with $300-400 \mathrm{mg} / \mathrm{d}$ as preformed $20: 5 n-3$ and $22: 6 n-3$. Indeed, consumption of up to $1 \mathrm{~g} / \mathrm{d}$ of $20: 5 n-3$ and $22: 6 n-3$ has been advised and in patients with cardiovascular disease positive benefits may be gained from consuming at least $3 \mathrm{~g} / \mathrm{d}$ (Barlow et al. 1990). The main reason for incorporating 20:5n-3 and 22:6n-3 as preformed fatty acids, rather than relying on converting the body tissues from their precursor, $\alpha$-linolenic acid, $18: 3 n-3$, is that there are concerns over efficiency and speed of conversion in man (Nettleton, 1991).

Based on the results in this experiment (Tables 4 and 6) and assuming that $100 \mathrm{~g} / \mathrm{d}$ is an appropriate figure for beef consumption (Enser et al. 1996), then it is feasible to calculate the contribution of $n-3$ fatty acids to the human diet. Consumption of $100 \mathrm{~g} / \mathrm{d}$ of beef muscle from cattle fed on the control, linseed, fish oil and mix treatments would provide $55 \cdot 2,82.4,77.6$ and $70.9 \mathrm{mg} / \mathrm{d}$ of $n-3$ fatty acids, including $13 \cdot 2,18 \cdot 4,27.6$ and $19.9 \mathrm{mg} / \mathrm{d}$ as $20: 5 n-3$ and 22:6n-3, respectively. Hence, beef from the linseed and fish oil treatments could supply between 41-82 and 39$78 \%$ of the daily recommended consumption of $n-3$ fatty acids, (100-200 mg/d, respectively). Further enrichment of the $n-3$ fatty acids in beef seems possible, since the deposition of 20:5n-3 in Japanese (Koizumi et al. 1991) and Australian (Mitchell et al. 1991) cattle exceeds the combined 20:5n-3 and 22:6n-3 deposition in this experiment. Although the levels of 18:1 trans were more than doubled as a result of feeding the concentrates containing $n$-3 PUFA they would not cause the COMA recommendation of a maximum of $2 \%$ of calories to be exceeded. Furthermore, there is doubt that ruminant 18:1 trans, mainly trans-vaccenic acid, are a significant risk factor for cardiovascular disease compared with trans fatty acids arising from chemical hardening of oils (Willett et al. 1993). Since the dietary PUFA supplements used in this study also increased tissue concentrations of conjugated linoleic acid (Enser et al. 1999) its reported antiatherogenic action may counteract the effects of increased trans 18:1 (Banni \& Martin, 1998). Further work is required to examine methods of protecting the $n$-3 PUFA, particularly from linseed, from rumen biohydrogenation and which would incidentally decrease the production of trans fatty acids. Greater knowledge of the genetic and enzymatic mechanisms influencing the synthesis and deposition of long-chain $n-3$ PUFA is also required.

\section{Acknowledgements}

This study was funded by the Ministry of Agriculture Fisheries and Food, Roche Products Ltd., International Fish 
Oil and Meal Manufacturers Association and Trident Feeds. The authors wish to acknowledge the technical assistance of W. J. Fisher, D. W. R. Davies, J. K. S. Tweed, K. Hallett, B. Hewett and statistical advice from M. S. Dhanoa.

\section{References}

Ashes JR, Siebert BD, Gulati SK, Cuthbertson AZ \& Scott TW (1992) Incorporation of $n-3$ fatty acids of fish oil into tissue and serum lipids of ruminants. Lipids 27, 629-631.

Banni S \& Martin JC (1998) Conjugated linoleic acid and metabolites. In Trans fatty acids in human nutrition, pp. 261302 [W Sebedio and W Christie, editors]. Dundee: The Oily Press.

Barlow SM, Young FVK \& Duthie IF (1990) Nutritional recommendations for $n-3$ polyunsaturated fatty acids and the challenge to the food industry. Proceedings of the Nutrition Society 49, 13-21.

Bauchart D, Verite R \& Remond B (1984) Long-chain fatty acid digestion in lactating cows fed fresh grass from spring to autumn. Canadian Journal of Animal Science 64, Suppl. 1, 330-331.

Cant JP, Fredeen AH, MacIntyre T, Gunn J \& Crow N (1997) Effect of fish oil and monensin on milk composition in dairy cows. Canadian Journal of Animal Science 77, 125-131.

Chilliard Y \& Doreau M (1997) Influence of supplementary fish oil and rumen-protected methionine on milk yield and composition in dairy cows. Journal of Dairy Research 64, $173-179$.

Clinquart A, Istasse L, Dufrasne I, Mayombo A, van Eenaeme C \& Bienfait JM (1991) Effects on animal performance and fat composition of two fat concentrates in diets for growingfattening bulls. Animal Production 53, 315-320.

Cook LJ, Scott TW, Faichney GJ \& Lloyd Davies H (1972) Fatty acid interrelationships in plasma, liver, muscle and adipose tissue of cattle fed safflower oil protected from ruminal hydrogenation. Lipids 7, 83-89.

Dawson JM, Buttery PJ, Lammiman LJ, Soar JE \& Essex CP (1991) Nutritional and endocrinological manipulation of lean deposition in forage fed steers. British Journal of Nutritional 66, $171-185$.

Department of Health (1994) Report on health and social subjects No. 46. Nutritional aspects of cardiovascular disease. London: HMSO.

Dewhurst RJ, Aston K, Fisher WJ, Evans RT, Dhanoa MS \& McAllan AB (1999) Comparison of energy and protein sources offered at low levels in grass-silage-based diets for dairy cows. Animal Science 68, 789-799.

Eaton SB, Eaton SB III, Konner MJ \& Shostak M (1996) An evolutionary perspective enhances understanding of human nutritional requirements. Journal of Nutrition 126, 1732-1740

Enser M, Hallett K, Hewett B, Fursey GAF \& Wood JD (1996) Fatty acid content and composition of English beef, lamb and pork at retail. Meat Science 42, 443-456.

Enser M, Scollan ND, Choi NJ, Kurt E, Hallett K \& Wood JD (1999) Effect of dietary lipid on the content of conjugated linoleic acid (CLA) in beef muscle. Animal Science 69, 143146.

Folch J, Lees M \& Stanley GHS (1957) A simple method for the isolation and purification of lipids from animal tissues. Journal of Biological Chemistry 226, 497-509.

Harfoot CG \& Hazlewood GP (1988) Lipid metabolism in the rumen. In The Rumen Microbial Ecosystem, pp. 285-322 [PN Hobson, editor]. London, New York: Elsevier Applied Science. Hay JD \& Morrison WR (1972) Positional isomers of cis and trans monoenoic fatty acids from ox (steer) perinephric fat. Lipids $\mathbf{8}$, 94-95.

Hwang DH, Boudreau M \& Chanmugam P (1988) Dietary linolenic acid and longer-chain $n$-3 fatty acids: comparison of effects on arachidonic acid metabolism in rats. Journal of Nutrition 118, 427-437.

Kempster AJ, Cook GL \& Grantley-Smith N (1986) National estimates of the body composition of British cattle, sheep and pigs with special reference to trends in fatness. A review. Meat Science 17, 107-138.

Kennelly JJ (1996) The fatty acid composition of milk fat as influenced by feeding oilseeds. Animal Feed Science Technology 60, 137-152.

Kimoto WI, Ellis R, Wasserman AE, Oltjen R \& Wrenn TR (1974) Fatty acid composition of muscle phospholipids from calves and growing and mature steers fed protected safflower oil. Journal of Food Science 39, 997-1001.

Koizumi I, Suzuki Y \& Kaneko JJ (1991) Studies on the fatty acid composition of intramuscular lipids of cattle, pigs and birds. Journal of Nutritional Science and Vitaminology 37, 545-554.

Mandell IB, Buchanan-Smith JG, Holub BJ \& Campbell CP (1997) Effects of fish meal in beef cattle diets on growth performance, carcass characteristics and fatty acid composition of longissimus muscle. Journal of Animal Science 75, 910-919.

Mansbridge RJ \& Blake JS (1998) Nutritional factors affecting the fatty acid composition of bovine milk. British Journal of Nutrition 78, Suppl. 1, S37-S47.

Marmer WN, Maxwell RJ \& Williams JE (1984) Effects of dietary regimen and tissue site on bovine fatty acid profiles. Journal of Animal Science 59, 109-121.

McDonald IW \& Scott TW (1977) Foods of ruminant origin with elevated content of polyunsaturated fatty acids. World Review of Nutrition and Dietetics 26, 144-207.

Mills EW, Comerford JW, Hollender C, Harpster HW, House B \& Henning WR (1992) Meat composition and palatability of Holstein and beef steers as influenced by forage type and protein source. Journal of Animal Science 70, 2446-2451.

Mitchell GE, Reed AW \& Rogers SA (1991) Influence of feeding regime on the sensory qualities and fatty acid contents of beef steaks. Journal of Food Science 56, 1102-1103.

Morgan CA, Noble RC, Cocchi M \& McCartney R (1992) Manipulation of the fatty acid composition of pig meat lipids by dietary means. Journal of the Science of Food and Agriculture 58, 357-368.

Nettleton JA (1991) $\omega-3$ fatty acids. Comparison of plant and seafood sources in human nutrition. Journal of the American Dietetic Association 91, 331-337.

Ratnayake WMN, Ackman RG \& Hulan HW (1989) Effect of redfish meal enriched diets on the taste and $n$-3 PUFA of 42day-old broiler chickens. Journal of Science Food and Agriculture 49, 59-74.

Scollan ND, Fisher WJ, Davies DWR, Fisher AV, Enser M \& Wood JD (1997). Manipulating the fatty acid composition of muscle in beef cattle. Proceedings of the British Society of Animal Science, 20.

Scollan ND, Choi NJ, Maeng WJ, Enser M \& Wood JD. Digestion of long chain fatty acids from differing feed sources and their effect on the rumen function of steers. Journal of Agricultural Science, Cambridge (In the Press).

Scott TW \& Ashes JR (1993) Dietary lipids for ruminants: protection, utilization and effects on remodelling of skeletal muscle phospholipids. Australian Journal of Agricultural Research 44, 495-508.

Van Elswyk ME, Sams AR \& Hargis PS (1992) Composition, functionality and sensory evaluation of eggs from hens fed manhaden fish oil. Journal of Food Science 57, 342-344.

Weber PC, Sellmayer A \& Hrboticky N (1993) Are we what we 
eat? Fatty acids and their diverse functions. In Lifestyle diseases and the human diet: a challenge to future food production. Proceedings of the 44th Annual Meeting of the European Association for Animal Production, pp. 19-27. Foulum, Denmark: National Institute of Animal Science.

Willett WC, Stampfer MJ, Manson JE, Colditz GA, Speizer FE,
Rosner BA, Sampson LA \& Hennekins CH (1993) Intake of trans fatty acids and risk of coronary heart disease among women. Lancet 341, 581-585.

Wonsil BJ, Herbein JH \& Watkins BA (1994) Dietary and ruminally derived trans-18:1 fatty acids alter bovine milk lipids. Journal of Nutrition 124, 556-565. 